\title{
The Last Shot
}

Ludwig Gutmann, MD

Neurolog ${ }^{\circledR}$ 2021;97:188-190. doi:10.1212/WNL.0000000000011923
Correspondence

Dr. Gutmann

lud-gutmann@uiowa.edu

The rhythmic creaking of the rocking chair broke the silence of the moment. The chair's weathered features matched those of the old man rocking quietly. The size of the chair seemed mammoth for his emaciated frame, wasted away by age. Rocking in the chair was his favorite pastime, sitting on the shaded front porch of the family farmhouse, surrounded by the prairie grassland stippled with wildflower pastels. He barely noticed the silhouette of the town sitting on the wooded horizon, its church and adjacent cemetery long forgotten. Sometimes he would nap but mostly he liked watching the swallows flit around the porch or the manic chipmunks madly chasing each other.

It didn't matter that he no longer knew whose farmhouse he was living in or why he was there. What was important was that the people living there took care of him. He especially liked the woman and the young man who helped her. That they were his daughter and grandson had gotten lost years ago.

His daughter, Emma, was inside the house preparing dinner for her menfolk. Occasionally, she'd check on her father through the open front door that led to the porch. He had wandered off once too often and the reins that tied him into his chair were his security strap. Emma and her husband, Luke, had decided the spare set hanging in the barn would solve the problem. To everyone's surprise, Calvin didn't mind it one bit. Said it reminded him of being back on his horse.

Emma stepped on the wooden porch, bent over to kiss him on his forehead. She had cut his long unruly white hair and shaved off his scraggly beard when her son, Jeremiah, had first brought him to the farm years ago. He'd been living with her brother, but it had become too difficult for him to look after their father. Sitting there, his hair neatly combed and his beard a mere silvery stubble, he didn't have the bedraggled appearance he had when he first arrived. Along with most of his memories, the frontier look was now part of the past.

Calvin had been the town sheriff of Derecho it seemed forever. At least to Emma. She couldn't remember his not being sheriff. He'd been tough but the town loved him for his ability keep the drunken brawls and gun fights to a minimum. The saloon keepers knew the limits of his tolerance. His skill with a gun was legendary, as was his ability to find peaceful solutions to vexing problems.

He seemed happy. Being sheriff was now behind him. He was often confused and had problems recalling details and past events, but he always went along with anything Emma or Luke wanted or what they said. Her son, Jeremiah, was devoted to his gramps-especially ever since he had saved the boy's life in the now famous stagecoach episode.

Luke and Jeremiah came on the porch having just washed up after spending the afternoon in the cow barn.

“Time for dinner," Emma announced.

Calvin never missed the call to eat. He tried getting out of the rocker, pushing on the arm rest without success. The 2 men, as they always did, untied the reins, took his arms, and helped lift him out of the chair. His tiny steps were slow and wobbly, but Calvin made it to the big front room. Luke and Jeremiah let go of his arms as he sat down at the head of the table, a seat Emma 
had assigned to him years before. These were his waning years but, for Emma, he was still the head of the family.

Sitting in the middle of the table was a small chocolate cake. Emma had been talking about making a chocolate cake for some weeks now, after a traveling salesman had sold her a tin of cocoa and given her a recipe from a Philadelphia newspaper. The article had said that chocolate was good for people's memory and that really caught her attention. She had put a freshly picked daisy in the middle of the cake.

"Must be some kind of special celebration," Luke half said, half asked.

"It is," Emma answered. "Today is the tenth anniversary of the stagecoach holdup where Pap saved Jeremiah's life. It's a special day."

“And everyone else's life, too,” Jeremiah added. He had only been a boy, but the events of the attempted robbery were still indelibly branded in his mind. They were the origin of his worst nightmares.

As it turned out, it had been one of the finest days in Calvin's life. Standing half hidden in the shadows of the stalled stage, his 2 shaky hands holding the gun that had been buried in his shoulder holster, he maimed the 3 outlaws with 3 quick shots in succession. It became a legend in the town of Derecho and the whole new state of Iowa. The old retired sheriff was performing one last encore.

Everyone turned to look at Calvin for a moment. Emma clapped her hands. Calvin looked back blankly, his eyes fixed on the chocolate cake and its floral ornament. He was waiting for the food. It was time to eat. Emma tied the eating towel around his neck. His hands had gotten less shaky since the stagecoach episode, but a lot of the food still ended up on the towel. He insisted on a piece of the cake before he let Emma serve the stew.

The next morning, Calvin was back on the porch in his rocking chair. The prairie flowers now in full bloom-blackeyed Susans, butterfly weed, daisies - distracted Calvin from seeing the small whirlwind of dust in the distance. Jeremiah had seen it as he had helped Calvin walk across the porch. As it got closer, it unveiled 2 horses and their riders coming up the wagon road toward the house.

One of the men tied his horse to the hitching post in front of the porch. The other remained on his horse, making no move to dismount. Their faces had the look of brothers - the sameshaped noses and eyes that looked like they could burn holes in you. Neither man smiled.

"We're looking for Sheriff Tate," the first man said to Luke, his wide-brimmed hat pushed back, exposing his balding forehead. His beard would have matched the color of the hat if it didn't have all those flecks of white in it. "They say he lives someplace around here."

Emma stood in the doorway, Jeremiah half-hidden behind her. He had recognized both men. They were 2 of the stagecoach outlaws. His nightmare was becoming a reality. Luke had stepped partway down the porch steps. Calvin was smiling, watching 2 eagles soaring high off to one side of the house.

"Why are you looking for him?” Luke asked.

"Well," the young gunman began, "some years ago me and my 2 brothers had a run-in with him and we ended up in prison. All 3 of us got shot up by him. One of my brothers never come out of it. Died. My brother on that horse back there never been able to walk right since. We just wanna have a chat with him and see how he feels about what he done to us." $\mathrm{He}$ paused. "Know where we can find him?"

Calvin still had his eyes fixed on the 2 eagles floating over the cows grazing in the nearby meadow. "Must be turkey buzzards, too big for crows," he said to no one in particular.

"Yes," Luke answered the men, "we can tell you where to look."

Jeremiah was frightened. They were here to kill Gramps and there was no way to stop them. He knew the whole family would get killed if they tried. This was Jeremiah's most terrifying fear. He stepped back into the shadows of the front parlor. He was afraid the men might recognize him, never mind the holdup had occurred 10 years ago when he was still just a kid.

Calvin was still watching the birds. "Nope, ain't buzzards," he said. "Doubt I ever seen birds like that before."

"Can you shut that old guy up?" The man adjusted his gun belt.

"Don't pay any attention to him," Luke answered. "He lives in another world."

"The sheriff," the gunman was getting impatient. "How do we get to the sheriff?"

"Buried in the church cemetery," Luke said quietly. "Sheriff Tate died 10 years ago. His family got him the biggest headstone up there. Can't miss it."

Calvin looked over at Luke. "I don't know, only birds there by the cemetery are those pesky crows and these guys are too big for crows."

The gunman ignored the old man. "What he die of? Get killed in a gun fight?" 
"I don't rightly know," Luke answered, "but they say his heart just give out."

The gunman turned away from the porch and untied his horse. "Me and my brother are riding over to the cemetery and take a closer look at that grave. We're obliged to you. Thanks for the tip."

Calvin was still preoccupied with the soaring birds. "Dadburnit, them must be hawks." He frowned. "It sure is hard to tell about birds anymore."

For a few minutes, the rest of the family watched the 2 gunmen ride down the gentle hill toward the town cemetery. Luke remembered that conversation he and Emma had with Calvin when he first arrived at the farm. They thought it was a crazy idea but decided to indulge him. The neighbors understood and had agreed to keep it all a secret.

As the 2 strangers disappeared behind some trees, Luke was just now realizing the wisdom of Calvin's request. He put an arm around Jeremiah's shoulder and pulled him close.

"When you brought Gramps here 10 years ago so we could all help look after him, this is what he was worried to death about. That those gunmen and outlaws he put into prison would be coming back for revenge. He knew he could never defend himself. It was his idea then to put up the tombstone."

\section{Note}

This story is a sequel to "The Old Sheriff," published previously in Neurology ${ }^{\circledR}$ (2014;82:2142-2144). 


\title{
Neurology
}

\author{
The Last Shot \\ Ludwig Gutmann \\ Neurology 2021;97;188-190 Published Online before print April 15, 2021 \\ DOI 10.1212/WNL.0000000000011923
}

This information is current as of April 15, 2021

Updated Information \& Services

Subspecialty Collections

Permissions \& Licensing

Reprints including high resolution figures, can be found at:

http://n.neurology.org/content/97/4/188.full

This article, along with others on similar topics, appears in the following collection(s):

All Cognitive Disorders/Dementia

http://n.neurology.org/cgi/collection/all_cognitive_disorders_dementia Cognitive aging

http://n.neurology.org/cgi/collection/cognitive_aging

Inclusion, Diversity, Equity, Anti-racism, and Social Justice

(IDEAS)

http://n.neurology.org/cgi/collection/all_equity_diversity_and_inclusio $\mathrm{n}$

Information about reproducing this article in parts (figures,tables) or in its entirety can be found online at:

http://www.neurology.org/about/about_the_journal\#permissions

Information about ordering reprints can be found online:

http://n.neurology.org/subscribers/advertise

Neurology ${ }^{\circledR}$ is the official journal of the American Academy of Neurology. Published continuously since 1951, it is now a weekly with 48 issues per year. Copyright (O) 2021 American Academy of Neurology. All rights reserved. Print ISSN: 0028-3878. Online ISSN: 1526-632X.

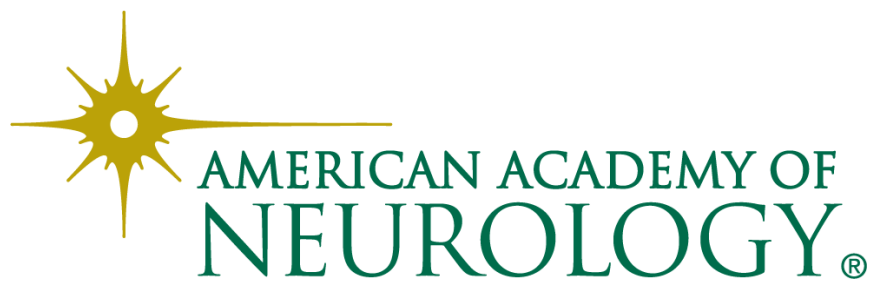

